\title{
The Impacts of the American-Chinese Trade War and COVID-19 Pandemic on Taiwan's Sales in Semiconductor Industry
}

\author{
Tristan Kempf ${ }^{1}$, Vito Bobek ${ }^{1} \&$ Tatjana Horvat ${ }^{2}$ \\ ${ }^{1}$ University of Applied Sciences FH Joanneum, Graz, Austria \\ ${ }^{2}$ University of Primorska, Faculty of Management, Koper, Slovenia \\ Correspondence: Tatjana Horvat, University of Primorska, Faculty of Management Cankarjeva 5, 6000 Koper, \\ Slovenia. Tel: 386-4034-0835. E-mail: tatjana.horvat@fm-kp.si
}

Received: February 5, 2021

Accepted: March 12, 2021

Online Published: March 20, 2021

doi:10.5539/ijef.v13n4p62

URL: https://doi.org/10.5539/ijef.v13n4p62

\begin{abstract}
The following paper deals with the American Chinese trade war and its impacts on Taiwan's economy, particularly sales in Taiwan's semiconductor industry. Indeed, trade tensions impact global supply chains, especially in the semiconductor industry, since its supply chain is highly globalized and dependent on many companies in various countries. Hence, the industry is susceptible to trade disruptions. With the largest microchip manufacturer TSMC, Taiwan is one of the key players in the fabrication of microchips. It has strong cultural, geographical, and economic ties to China and, on the other hand, strong economic and military relations to the United States. A trade war between those two countries is an enormous future challenge for the island. However, this paper proves that trade tensions had a lower-than-expected impact on Taiwan's economy and the microchip industry. Due to capital that diverted from China to Taiwan and investments from Taiwanese companies in other countries like the USA. Additionally, Taiwan handled the Covid-19 pandemic extraordinarily well and therefore did not have any significant economic restrictions in the domestic market. Now it depends on the future action steps of the Taiwanese industry and government. If Taiwan manages to steer outgoing companies from China to Taiwan, the island could emerge as the surprise winner of the trade dispute. For this purpose, the paper gives concrete recommendations on how to increase the attractiveness for FDI through tax benefits or infrastructure investments.
\end{abstract}

Keywords: Semiconductors, Taiwan, US-China tensions, trade war, trade dispute

\section{Introduction}

Taiwan is a small but economically significant island located in the South China Sea. It gained independence in 1950 after the nationalist leader Chiang Kai-Shek lost the civil war to Mao Zedong and fled to Taiwan. Chiang Kai-Shek was ruling Taiwan strictly till 1975. In this period, Taiwan experienced massive economic growth and industrial development. In 1979 the US government promised in the Taiwan Relations Act to support Taiwan's independence and provide help defending the island if necessary. They were making the United States one of Taiwan's most important partners in economic trade and independence and national defense. Mainland China though managed to assert that most countries have official diplomatic ties with China only. Due to China's One-China policy, China insists that a nation cannot have diplomatic relations with China and Taiwan at the same time (BBC, 2019; Hsieh, 2020, 62ff). Despite its global isolation, Taiwan became an essential hub for technology and one of the leading producers of advanced electronic goods.

Mainland China is Taiwan's largest trading partner in total trade (23\%) and imports (19\%), followed by the United States, accounting for $12 \%$ of total trade. Other important trading partners of Taiwan are Japan, Hong-Kong, South Korea, and Germany (Johnson, 2017, p. 7). Taiwan's strong exports in the 2020 Covid-19 crisis are due to the tremendous growth of Taiwan's most significant enterprise: Taiwan Semiconductor Manufacturing Company (TSMC). The world's largest foundry (Taiwan Semiconductor Manufacturing Company, 2020) of semiconductors plays a significant role in Taiwan's economic success. Taiwan has made a successful shift from producing agricultural products towards industrial goods. There was another shift on the road to capital and technology demanding industries from labor-intensive industries in the last years. This can be mostly seen in the case of Acer or Asus. Both brands are, and most were, globally recognized PC producers headquartered in Taiwan. The Tiger State was one of the leading players in worldwide PC production. After the 
Internet era and the emergence of mobile devices, the economic change from producing computers to highly technological and advanced semiconductors, for instance, can be witnessed. Nowadays, one challenge of Taiwan's economy is software development. Hardware and production are well established, while big software giants like Google, Amazon, or Facebook are rising rapidly. To remain competitive in the electronic market, hardware like computers or semiconductors is essential, and the creation of software products. Furthermore, in the end, combining both skills for successful economic development (Ching, 2013).

The paper will research the economic impacts the trade war had on three economic figures in Taiwan. The authors will answer two research questions:

RQ1: In what way does the US-Chinese trade dispute impact Taiwan's Economy?

RQ2: In what way does the US-Chinese trade dispute impact on sales in Taiwan's Semi-Conductor Industry?

\section{One hypothesis will be tested:}

H0: The Taiwanese Economy sees extraordinary economic changes after the implementation of tariffs

H1: The Taiwanese Economy does not see extraordinary economic changes after the implementation of tariffs

The secondary data will be collected from various sources. Journal articles, scientific papers, reports from economic organizations as well as newspaper articles were used. Since this topic is highly dynamic, and industry trends are constantly developing and changing, online research with the help of newspapers and reports from economic organizations or government organizations was also used. This work references papers from Chinese authors and American authors to maintain scientific neutrality.

\section{Taiwan: Overview and Economic Analysis}

When breaking down Taiwan's GDP per sector, it is visible that the distribution of the GDP changes annually towards industry and services. In 2019 services accounted for $62.1 \%$ of Taiwan's GDP followed by, industry (35.6\%) and agriculture (1.8\%) (National Bureau of Statistics of China, 2020a). Those numbers indicate that Taiwan is a developed country, having most of its economic output from industry and services. Whereas agriculture only plays a minor role.

Another factor to visualize the economic power of a country is the unemployment rate, which is $3.7 \%$ (National Bureau of Statistics of China, 2020b) relatively low, also Taiwan scores $15^{\text {th }}$ place in the Ease of doing Business Index, an indicator of how conducive the regulatory environment is for starting a business (World Bank, 2019).

In terms of GDP growth, Taiwan achieved to increase its GDP by 3.3\% in Q3 2020 compared to Q3 2019, making it the fastest-growing quarter for the last four years, despite this global disease. Compared to other nations, Taiwan experienced a fast recovery in the Covid-19 crisis. Mainly due to its previous experience with SARS, Taiwan acted with quick travel restrictions and isolation policies. Taiwan only had 553 reported cases with seven deaths and completed more than 200 days without any new infection on the island. The comparably mild pandemic development and no lockdowns resulted in a fast-economic recovery and a rebound of domestic demand due to government stimulations. Lastly, the ongoing trade conflicts between China and the US resulted in a boost of Taiwanese exports to China before the Huawei ban was put in place by the US government in Q4 2020 (Miaojung et al., 2020; Wu \& Ellis, 2020). More will be explained in the chapter: "Impacts on Taiwan's Economy."

Mainland China is Taiwan's largest trading partner in total trade (23\%) and imports (19\%), followed by the United States, accounting for $12 \%$ of total trade. Other important trading partners of Taiwan are Japan, Hong-Kong, South Korea, and Germany (Johnson, 2017, p. 7). Taiwan's strong exports in the 2020 Covid-19 crisis are due to the tremendous growth of Taiwan's most prominent enterprise: Taiwan Semiconductor Manufacturing Company (TSMC). The world's largest foundry (Taiwan Semiconductor Manufacturing Company, 2020) of semiconductors plays a significant role in Taiwan's economic success. Taiwan has made a successful shift from producing agricultural products towards industrial goods. There was another shift on the road to capital and technology demanding industries from labor-intensive industries in the last years. This can be mostly seen in the case of Acer or Asus. Both brands are, and most were, globally recognized PC producers headquartered in Taiwan. The Tiger State was one of the leading players in worldwide PC production. After the Internet era and the emergence of mobile devices, the economic change from producing computers to highly technological and advanced semiconductors, for instance, can be witnessed. Nowadays, one challenge of Taiwan's economy is software development. Hardware and production are well established, while big software giants like Google, Amazon, or Facebook are rising rapidly. To remain competitive in the electronic market, hardware like computers or semiconductors is essential, and the creation of software products. Furthermore, in 
the end, combining both skills for successful economic development (Ching, 2013).

\section{US-China Tensions: Reasons for Escalation}

Back in 2019, the IMF already warned that the two most significant threats to international growth are a No-Deal Brexit and an increasing trade war between China and the United States. In 2018 the Trump administration introduced tariffs on $\$ 250 \mathrm{bn}$ on hundreds of Chinese products imported into the US. On the other hand, China answered with tariffs on $\$ 110 \mathrm{bn}$ of US products. With increased tariffs and the continuous destruction of free trade, both sides would suffer from those decisions. A look at the numbers tells that the US imports are worth more than $\$ 500$ bn from China, whereas China only buys products worth around $\$ 120 \mathrm{bn}$ from the United States (Blakeley, 2019, p. 17). However, not only China but also the US will suffer from those tensions in the long run. Due to an expected decrease in the demand for Chinese goods, the economy could further slow-down. Mainly because the US economy has grown exceptionally well in recent years, a peak followed by a decline of the economy can be expected soon.

Further trade-restrictive measures could worsen economic development and could cause an earlier and harder recession. Additionally, trade barriers will influence countries' economic development that trade with both parties, like Taiwan also, the global GDP is expected to decrease. This is hard to express in numbers due to the COVID-19 pandemic and whether the two nations' trade tensions also impacted the current economic situation. As the current trade war became more apparent, the next chapter will shortly analyze the trade war's origins. Since heavy tariffs and conflicts do not happen overnight, it is also relevant to understand the semiconductor industry's impacts to understand the origins. Hence, the development of this trade dispute is briefly explained.

In 1971, President Richard Nixon prepared a US-Chinese trade relationship by declaring China to a Most Favored Nation (MFN). This status foresaw equal treatment in terms of tariffs and trade barriers. Meaning the US installs the same tariff trade barriers towards China as the Chinese governments do towards the US. However, this agreement was needed to be renewed annually by US congress. In 1999 the MFN status ended, and China entered the WTO in 2001. Both countries soon became each other's most important trading partners, and bilateral trade grew at a fast pace (Guo et al., 2018, 106ff). In the following, three illustrative reasons are explained why the trade conflict escalated.

\subsection{Trade Imbalance}

Current US-President Donald Trump was criticizing China's trade surplus with the US heavily. Especially during his campaign. The New York Times even said that part of the reason he won the presidential race was accusations against the American trade deficit or China's trade surplus on the bilateral trade (Gladstone, 2020). Though criticizing China's trade policy is not Donald Trump's creation. In 2005, Republican politicians complained about the US-trade deficit with China (Moosa et al., 2020, p. 1).

Statistics indicate that, between the years 2000 and 2016, the USA imported more China products than China purchased from the US. The trade surplus in China increased vastly. In 2000 the surplus was $\$ 30 \mathrm{bn}$, 15 years later already $\$ 261 \mathrm{bn}$. However, apart from Chinas exports, also US imports increased massively from $\$ 52 \mathrm{bn}$ in 2000 up to $\$ 410 \mathrm{bn}$ in 2016. Primary goods traded were steel, textiles, machines, and computers from the Chinese side, whereas the US exports mainly aerospace products, seeds, grains, motor vehicles, or semiconductors (Guo et al., 2018, 107f; Loesche, 2018).

One of the biggest concerns of the US administration were Chinese steel imports. The US government accused China of dumping American steel prices with highly subsidized Chinese steel. Despite the Chinese trade surplus, also the US benefited from the increasing trade volume. Firstly, US companies could produce cheaper and less regulated in China. Secondly, US shoppers consumed cheaper Chinese made products. Lastly, also US companies exported agricultural products or technologically advanced products such as aerospace parts or semiconductors to China.

\subsection{The Devaluation of the Chinese Currency}

Certain US politicians and economists criticized that one cause of the trade imbalance is the Chinese currency's undervaluation: Yuan. China was accused of being a currency manipulator and criticized for holding the currency far below its actual market value (Wolverson, 2011). The exchange rate dispute goes back to 1998 when the Yuan was pegged to the US dollar in Asia's financial crisis. At the same time, China sold foreign assets (mainly dollars) to stabilize its currency towards the US dollar. In 2005 when the SARS pandemic was hitting Asia, China expected an economic recession and revalued its currency-followed by an almost $20 \%$ appreciation against the DollarDollar. Economists accused china of switching back to a fixed exchange rate while not publicly announcing it. The economist and founder of the American think tank PIIE, Fred Bergstein, 
announced in 2010 that during a public hearing on China's Exchange Rate Policy at the US House of Representatives, the Chinese renminbi is undervalued by about $40 \%$ against the DollarDollar.

Additionally, he lists that the Chinese government buys around $\$ 1$ bn dollars daily to push down the currency and prevent it from rising (Bergstein, 2010). Further, he claims that this measurement is a form of protectionism that artificially subsidizes Chinese goods worldwide. This would also be against the IMF rules, not allowing a country to manipulate the exchange rate to gain an unfair competitive advantage. Interestingly, when comparing the two currencies today with the help of the BIG MAC INDEX, it shows that the Chinese Yuan is undervalued by $45 \%$, roughly the number economist Bergstein mentioned. Back in 2010, it was about the same value (The Economist, 2020).

Proofing the undervaluation of the Yuan with the Big Mac Index is way too simple. Firstly, other countries like South Africa or Taiwan also undervalue comparably to the DollarDollar in the Big Mac Index and are not or less criticized. Secondly, economists and newspapers do not all agree on the Yuan overvaluation. The weekly US newspaper Barron wrote that the Yuan was undervalued due to the Chinese capital flight towards Canada and the US. Where Chinese individuals buy businesses and properties overseas (Forsyth, 2016).

Furthermore, the relatively fast Covid-19 recovery and regained economic growth could also lead to further Chinese FDI into European or US American companies. Before COVID-19 in 2018, Chinese entities invested $11.7 \mathrm{bn} €$ in EU countries and \$25bn into the US, most of the capital flowed into mergers and acquisitions (Braw, 2020). When analyzing the problematic financial situation for many companies caused by lockdowns and sales restrictions, this number is expected to grow even further-resulting in an outflow of the Yuan.

Indeed, Chinas monetary policy can be criticized; however, whether the policies made are giving China an unfair comparative advantage is very debatable and might not justify strict trade barriers. Finally, several papers studied this exact question, and empirical studies attest the US concern as unfounded (Murthy \& Kalsie, 2019, p. 297) and disprove the Yuan's overvaluation (Moosa et al., 2020, p. 14).

\subsection{The Technological Conflict}

US administration blamed China for embezzling American technology and violating intellectual property resulting in a boycotting of China's largest tech company Huawei, which directly affects Huawei's 5G network plans in other countries. For example, Great Britain and Poland excluded Huawei from their 5G plans as well, other countries like Germany tightened market entry barriers (Gladstone, 2020).

With the implementation of tariffs, the US also expects to reduce China's technological capacity (Kapustina et al., 2020, p. 6). One main dispute is the creation of joint ventures when foreign firms enter China. This can provide risk in terms of intellectual property and technological transfers to Chinese companies. Trade secrets and sensitive data could be transferred to third parties or misused by the Chinese partner. Again, also, this section is not only concerning US interests. Also, European or Japanese enterprises are aware of the risks a joint venture with a Chinese partner can cause. One example is the swift creation of a Chinese Highspeed Rail (HSR) network. It went from almost nothing in 2000 to the largest in the world, in only one decade. The main reason for this was the cooperation with the Japanese, German, and French train companies, specialized in highspeed networks. The principle of -exchanging markets for technology- was efficiently applied. The result is a highly advanced HSR network which not only boosts domestic infrastructure but could even allow China to export the technology to other countries (Chen \& Haynes, 2016, 1ff). However, as this example illustrates, companies are not forced to share knowledge with Chinese companies. However, they often feel the Chinese market is too important to be missed and agree on deals.

Perhaps not always considering the long-term consequences. Already under the Obama administration, Chinese M\&A activity was rejected due to national security concerns. Aixtron, a German semiconductor company, was bought by the Chinese Fujian Group. The US government intervened as they feared the usage of nuclear programs. The US had the right to intervene since Aixtron had a California plant (Mozur, 2016). However, government interventions happened hardly ever. The US newspaper POLITICO found in an investigation that US officials intervene too little, and authorities do not intervene enough to secure sensitive American technology. The increased Chinese M\&A appetite on US tech companies, often below the governing authority's radar, also led President Trump to declare the Trade War on China. Whether tariffs on goods are the right tool to prevent sensitive high-tech data from ending up in China is under intense debate (Bennett \& Bender, 2018).

\section{The Use and Creation of Semiconductors}

\subsection{Application}

According to the Electrochemical Society and an OECD report, Semiconductors (also known as computer chips, 
integrated circuits, or microelectronic chips) is the reason for the correct operation of all kinds of electronic devices. A semiconductor is smaller than a postage stamp, and modern versions store billions of data. This is made possible due to silicon and germanium, which are the primary materials used. Those chemicals allow an exact flow of electric power (Eletrochemical Society, 2016; OECD, 2019, p. 11).

Semiconductors are found in various products: cell phones, computers, cars, televisions, electronic games, or even barcode-readers. Also, transistors and other devices are made of semiconductors that conduct electricity only weakly. Photovoltaic cells also use semiconductors that respond to light and generate electricity (Eletrochemical Society, 2016). The usage of consumer electronics is one of the main aspects. For example: Around five semiconductors are found in smartphones. Semiconductors are used for navigation, stabilizing the camera when filming, or detecting when the phone is being turned. In cars, semiconductors account for over $75 \%$ percent of modern vehicles' new technologic features such as infotainment systems or driver assistance and safety systems. Roughly 75 microchips are used when producing a new car (Bosch, 2019). For hybrid cars or electric cars, this number can even achieve up to 3,500 chips used (Michaela et al., 2020, p. 3). Lastly, highly developed semiconductors are indispensable for future technologies such as $5 \mathrm{G}$ networks, artificial intelligence, autonomous driving, or the latest medical equipment.

\subsection{Fabrication}

Semiconductors are an extremely globalized product. This is due to the complexity of the production process and highly specialized companies around the planet. In the following table, a semiconductor's globalized process is briefly explained: Therefore, the production process is explained in its order, production step, the company, and the country involved. This table should illustrate the complicated and global production process and the sensitivity of supply chain interruptions in sales on a whole industry, which is based on an open cross-border value chain for the movement of parts, machinery, and human resources.

Table 1. Production process of a semiconductor

\begin{tabular}{|c|c|c|c|}
\hline Order & Production Step & Company Involved & Country Involved \\
\hline 1st. & Chip architecture & ARM & United Kingdom \\
\hline 2nd. & Chip design based on Chip Architecture & AMD, Apple, Intel, or Qualcomm & USA \\
\hline 3rd. & $\begin{array}{l}\text { Wafer }{ }^{1} \text { production, silicon is shipped from, e.g., the US } \\
\text { to Japan and processed to a Wafer. }\end{array}$ & Sumco, Shin-Etsu & Japan \\
\hline 4th. & $\begin{array}{l}\text { Machinery producer supplying complex machines to } \\
\text { microchip production plants }\end{array}$ & ASML & The Netherlands \\
\hline 5th. & Foundries ${ }^{2}$ build microchips on customer orders. & TSMC, UMC & Taiwan \\
\hline 6th. & Chip connection, housing, and testing & Amkor & Singapore, Malaysia \\
\hline 7 th. & Installation in, e.g., smartphones, cars & Foxconn, Volkswagen & China, Germany \\
\hline 8th. & Sale of the finished product & e.g., Apple & Worldwide \\
\hline
\end{tabular}

${ }^{1}$ Wafers: Are disks on which the microchips are produced. They are round and consist of silicon or germanium.

${ }^{2}$ Foundries (manufacturing company): A company operating in semiconductors that manufactures products for other semiconductor companies.

Source: own design, based on: (Hohensee et al., 2020, p. 17; Platzer et al., 2020, 9ff).

\subsection{Impacts on Taiwan's Economy}

After understanding Taiwan's trade flows and GDP, analyzing the trade dispute between China and the US, and showing the sensitive global supply chain of semiconductor fabrication, possible impacts for Taiwan's economy are discussed. Taiwan has strong ties to China in the sense of cultural, geographical, and ethnic proximity. Furthermore, between 2009 and 2019, Taiwanese corporations invested more than $\$ 80 \mathrm{bn}$ into China to build up factories and benefit from lower labor and land costs in mainland China (NDC, 2019, p. 262). Simultaneously, China was not allowed to make any investments in Taiwan until 2009, when Taiwan slowly opened the country for Chinese FDI's in specific sectors only (NDC, 2019, p. 256). Due to its size, Taiwan's domestic market is limited. Additionally, Taiwan lacks natural resources like oil and gas, and therefore, needs international trade.

Taiwan locates the most critical foundries for semiconductors. Taiwan's largest company, TSMC, is also the world's largest semiconductors producer with a market share of 54\% (OECD, 2019, p. 21). TSMC is one of only three companies worldwide that can produce the new microchip standards sized $10 \mathrm{~nm}$ or smaller. This was one reason for the tech-giant apple to switch from Intel chips to their chips produced from TSMC. When speaking to investors, Intel openly considers outsourcing their 7nm chip production to TSMC (Chang, 2020; Michaela et al., 
2020, p. 14). Although TSMC is a market leader, the trade war could have adverse effects on TSMC and other semiconductor manufacturing companies in Taiwan. TSMC alone contributed nearly 5\% of the country's GDP (Taipei Times, 2019). In terms of sales, the semiconductor industry indeed suffered losses. Semiconductor revenues in 2019 shrank by $12.2 \%$ compared to 2018, according to the Semiconductor Industry Association (SIA). However, sales stabilized and grew, despite the pandemic and ongoing trade war, by $6 \%$ between Q4 2019 and Q4 2020 (Semiconductor Industry Association, 2020). One reason could have been the very high demand from Huawei. Until the trade ban with Taiwan came into force in September 2020, they imported large quantities of chips to ensure that production does not stop suddenly.

\section{Crucial Sets of Data}

Three illustrative figures are analyzed to see the impact the US-American trade war had and has on the Taiwanese economy:

1) Foreign direct investment

2) GDP growth

3) Unemployment rate

\subsection{Foreign Direct Investment}

Table 2. Taiwan's FDI's and the proportional China share

\begin{tabular}{lcccc}
\hline Year & Amount to foreign destinations & Amount to China & Total & China Share \\
\hline $\mathbf{2 0 0 9}$ & 3.006 & 7.143 & 10.148 & $70,38 \%$ \\
$\mathbf{2 0 1 0}$ & 2.823 & 14.618 & 17.441 & $83,81 \%$ \\
$\mathbf{2 0 1 1}$ & 3.697 & 14.377 & 18.073 & $79,55 \%$ \\
$\mathbf{2 0 1 2}$ & 8.099 & 12.792 & 20.891 & $61,23 \%$ \\
$\mathbf{2 0 1 3}$ & 5.232 & 9.190 & 14.422 & $63,72 \%$ \\
$\mathbf{2 0 1 4}$ & 7.294 & 10.277 & 17.570 & $58,49 \%$ \\
$\mathbf{2 0 1 5}$ & 10.931 & 10.965 & 21.897 & $50,08 \%$ \\
$\mathbf{2 0 1 6}$ & 12.123 & 9.671 & 21.794 & $44,37 \%$ \\
$\mathbf{2 0 1 7}$ & 11.573 & 9.249 & 20.822 & $44,42 \%$ \\
$\mathbf{2 0 1 8}$ & 14.295 & 8.498 & 22.792 & $37,28 \%$ \\
$\mathbf{2 0 1 9}$ & 5.455 & 2.822 & 8.277 & $34,09 \%$ \\
\hline
\end{tabular}

Source: own design based on (NDC, 2019, p. 262).

Table 2 shows the years 2009 until 2019 and the Taiwanese FDI activities in mainland China. The Chinese share of Taiwanese FDI has always been high, reaching $83 \%$ in 2010. Afterward, one can see a steady decrease. One significant decrease between 2015 and 2017 was probably due to increased political tensions between the two countries. As explained in the first chapter, China does not see Taiwan as a sovereign nation and wants to tie the country more closely to the mainland or even place it completely under Chinese administration. This shows that Taiwan's economy cannot be analyzed without seeing the unique political situation the country is in. The years marked in red color, 2018 and 2019, symbolize the trade tensions between the US and China. The China share was relatively stable in 2016 and 2017, but when the US government introduced tariffs, the FDI immediately declined by around $16 \%$ between 2017 and 2018 and roughly by another $8 \%$ in 2019 .

The reduced FDI activity in China is directly related to the trade war. In the sales of semiconductor industry, Taiwanese companies cannot trade with Chinese companies and American firms at the same time without paying high tariffs. TSMC lost with Huawei its largest Chinese based customer and the source of $13 \%$ of its revenue (Barrett, 2020). Therefore, costs are expected to rise. Re-routing and production shifts could lead to higher production costs. However, decreased FDI activity could also positively affect Taiwan and other countries in the following years. Southeast Asia's largest bank, Singapore's DBS, researched that more and more Taiwanese manufacturers leave China and increase investments in the Americas, India or go back home to Taiwan. Furthermore, it is a risk diversification, making Taiwanese FDI activities less dependent on one country. in the first month of 2019 alone, Taiwanese offshore companies invested almost \$7bn into Taiwan for relocating their businesses (Ma, 2019).

Shortly after the Huawei ban was announced, TSMC revealed it would build a \$12bn plant in Arizona, USA. Not only to be closer to its essential partners: Apple, Qualcomm, or Nvidia but also to gain more political influence in the US. China reacted with fighter jets that entered Taiwanese airspace (Barrett, 2020). 


\subsection{GDP Growth}

Another figure to analyze the economic performance of a country is GDP growth. The following table shows Taiwan's GDP growth annually between 2009 until 2021. Whereas the data for 2020 and 2021 was forecasted.

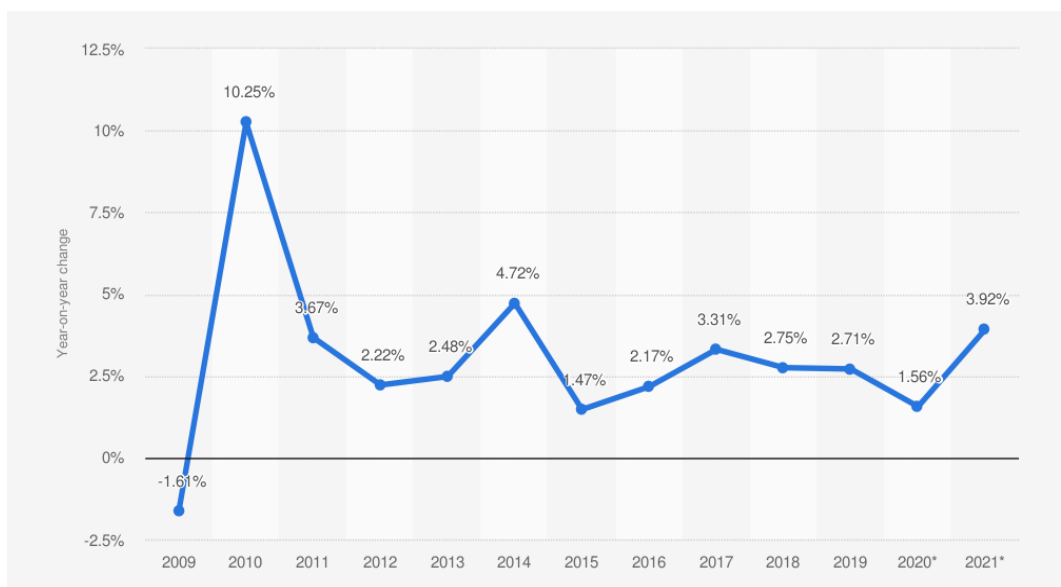

Figure 1. Annual change of the GDP in Taiwan from 2009 to 2019 with a forecast until 2021

Source: Taiwan National Statistics (2020).

Figure 1 shows negative growth during the financial crisis in 2009 and a quick recovery in the following years. Between 2011 and 2019, the GDP grew annually by around 3.4\%. Interestingly, in 2018 with the start of the trade war, the GDP growth did not change exceptionally and only decreased by $0.04 \%$ from 2018 until 2019. One explanation for this could be Taiwanese companies' return to the island, creating more goods, services, and overall value in Taiwan. Furthermore, it could make up for the negative impacts other firms could have had through trade restrictions. When analyzing the year 2020, GDP growth remains positive. This is particularly remarkable given that many countries experienced massive slumps. Due to strict lockdowns, travel, trade restrictions, and immense financial burdens on the national budget. Just for a comparison GDP growth in 2020 in the US: $-6 \%$, Germany: -7\%, UK: $-6.5 \%$ (IMF, 2020, p. 7).

Yes, Taiwan is still an emerging market, and emerging markets have higher economic growth, but a rapid and rigorous pandemic response helped the country immensely. They were handling the pandemic without a strict lockdown, which limited the economic damage. As well as keeping infections low was key to a comparably quick exit of the pandemic. However, the data does not distinguish what impact the pandemic situation had on Taiwan since trade restrictions could have also been one reason why GDP growth is below the ten-year average. Lastly, Q3 and Q4 of 2020 were due to the Huawei ban extremely well for Taiwan's exports. Since China does not have sufficient production capacities to produce semiconductors in a large amount themselves, the announced trade ban with Huawei resulted in an above-average demand from Huawei to prevent a production standstill. Which was the cause for a surge in Chinese exports by $22 \%$ in September only (Miaojung et al., 2020).

\subsection{The Development of the Unemployment Rate in Taiwan}

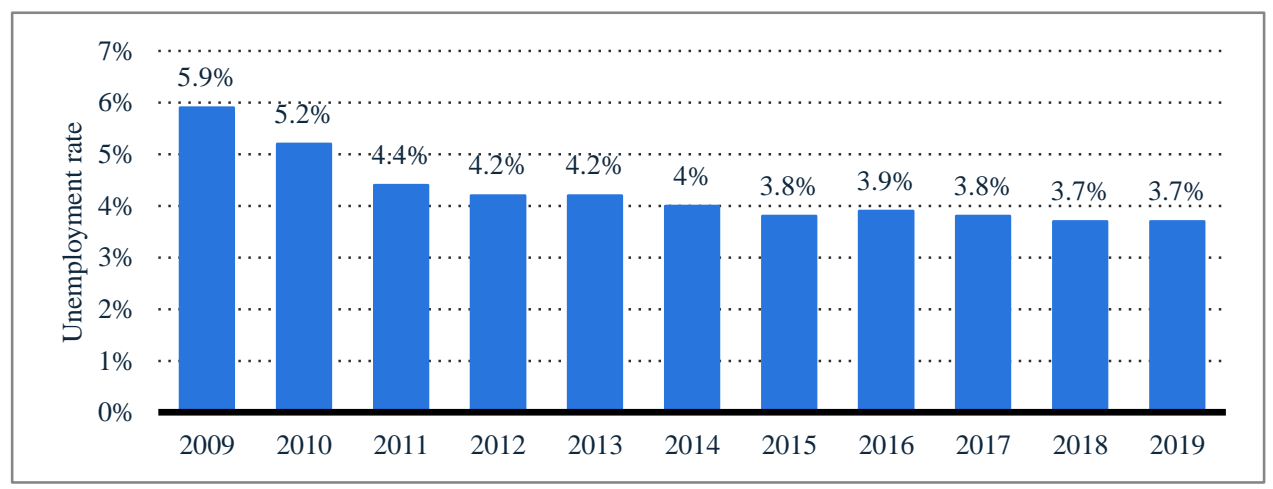

Figure 2. The unemployment rate in Taiwan from 2009 until 2019

Source: National Bureau of Statistics of China (2020b). 
Figure 2 shows the unemployment rate from 2009 until 2019 in Taiwan. Peak was during the financial crisis in 2009. Afterward, it nearly annually decreased and was at $3.7 \%$ in 2019, despite the trade ban. However, numbers for 2020 are not released yet, and a minor increase is expected due to Covid-19 and economic impacts. Because of the mild course of the pandemic, only a moderate increase is to be expected. Also, former Taiwanese offshore companies are expected to create value and jobs on the island.

Additionally, the government helped businesses and stimulated domestic demand. It was causing a surge of 5.1\% in domestic demand in Q3 2020. Also, authorities are subsidizing Taiwanese offshore companies' resettlement with tax benefits, faster 5G development, infrastructure investments, energy, and land benefits. Overall, \$38bn was added to Taiwan's economic support from the government side (Horton \& Wu, 2020; Miaojung et al., 2020).

\section{Results and Discussion}

\subsection{Implications for Taiwan's Economy}

When analyzing three economic factors on the Taiwanese economy, it became apparent that FDI to China was heavily reduced. The China share of Taiwanese outward investments dropped from $83.81 \%$ in 2010 to $34.09 \%$, which reduced around 59\%. This was not only due to trade restrictions the US imposed on China and vice versa. Before it sank because of political tensions between Taiwan and Mainland China, it is visible that investors feared further conflicts. The trade war only accelerated the process, either diverting Taiwanese investments to other countries or encouraging companies to relocate back to Taiwan. There is currently no sign that reduced China investment activity will hurt Taiwan's economy. It could lead to a buildup and growth of the national economy. This was also shown when researching the GDP growth in the past decade. Surprisingly, it only had a minor GDP decrease, although the trade war is ongoing and Covid-19 heavily disrupted global economic flows. GDP growth remained positive and could be up to $+1.9 \%$ for 2020 . This can be explained with several reasons. Firstly, the government's excellent virus management with isolating the island rapidly from global hotspot regions, including mainland China. Secondly, Taiwanese authorities supported the local demand with vouchers and financial help. Authorities also kept businesses, schools, universities, and public infrastructure open to avoid severe economic damage. Government measures also stabilized the last economic figure researched: the unemployment rate. Again, pandemic and trade war came together in 2019, and no severe impacts are seen neither on GDP growth nor on the unemployment rate. No increase in the unemployment rate can be explained on the one hand with diverted capital from mainland China back to Taiwan. Taiwanese offshore companies came back and invested \$38bn since 2019 (Horton \& Wu, 2020). US or EU-based companies could follow and relocate their Chinese subsidiaries to other places for future outlooks. Due to Taiwan's proximity and cultural bonding to China, some likely opt for the island.

\subsection{Implications on Taiwan's Semiconductor Industry}

At the beginning of the trade war, Taiwan and many other countries who have a share in the semiconductor supply chain were hit hard. However, for the world's largest semiconductor producer, TSMC, the second half of 2020 became a very profitable one. Exports to mainland China raised because American trade restrictions prohibited trade with Huawei and other Chinese companies who rely on semiconductor imports. China accounts for $60 \%$ of the global demand for semiconductors, mainly because international companies produce all kinds of electronic products. The difficulty for China lacks the know-how of technologically advanced semiconductors. Therefore, over $90 \%$ of China's chips are either imported or domestically made by foreign companies (Michaela et al., 2020, p. 26). The trade war resulted in a heavy burden for Chinese chipmakers. Since they cannot produce highly advanced chips themselves, or at least not in a sufficient amount, it will take four to five years for China to deliver the same standard as Taiwan or the US in the sales of semiconductor industry (Ramge, 2019, 22f).

On the other hand, Taiwan's industry immensely benefitted because Chinese manufacturers stockpiled chips mainly from TSMC. Resulted in high sales and record exports until September 2020. SMIC, China's government-supported microchip manufacturer, hoarded enough equipment to continue working for the next 18 months (King et al., 2020). By opening a plant in the US and relocating business to Taiwan, TSMC could emerge from the trade war as a beneficiary in the medium term. However, revenue from Huawei fell away. TSMC, as a global enterprise, has many other large customers like Apple or Nvidia. With opening its US plant, access to US companies gets more straightforward as well.

\section{Conclusion}

One would expect Taiwan's economy to suffer from the trade war between China and the US. Additionally, a global pandemic forced many countries to shut down its economy. Taiwan, though, did extraordinary well in 
fighting the pandemic. Its semiconductor companies managed to mitigate the conflict by relocating to Taiwan or other countries. Government aids and increased demand from China before the Huawei ban helped the economy. Although the sales of semiconductor industry is internationally intertwined and now disrupted, Taiwan profited immensely from diverted capital. A close link to China and its proximity make Taiwan an attractive target for companies shifting production back home, and international companies are expected to reallocate production facilities to Taiwan. Multinationals try to diversify their risk since many of them solely relied on Chinese production facilities. Indeed, Taiwan was facing an economic slow-down due to the trade barriers, as GDP decreased and FDI's diverted. Nevertheless, it is hard to estimate whether the 2020 dip in GDP growth is solely due to the trade ban or also due to the Covid-19 pandemic. Despite this, economic growth still maintained positive.

Semiconductor companies must carefully select whether they stick with the US and leave China behind, causing political and economic uncertainties alternatively, if they resume trade with Chinese companies, which results in a blockage of the US.

One of the most significant risks would be a division of the world into two parts. One half buys semiconductors from US production (presumably Western countries), and the other half relies on the, sooner or later developed, Chinese standard. In this context, it is to be expected that China will also provide financial aid in connection with the Silk Road, making financially vulnerable countries a target for the Chinese administration to increase political and economic influence. The burden for many companies would be huge, e.g., An Apple iPhone could not be sold in China and the US at the same time. Automakers using Chinese chips could not sell in the US and vice versa. Chinese and American standard versions would need to be developed in all kinds of areas. Even if this is a possible outcome of the trade dispute, economists confirm it is somewhat unrealistic (Ramge, 2019, p. 22).

Independently of the China-America tensions, Taiwan could be the secret winner of this war. The author recommends lifting Taiwan's attractiveness for FDI's. This could be done through enhancing the infrastructure, leading in 5G development, or merely financial and tax incentives to make Taiwan an attractive target for foreign companies. Mainly in the semiconductor and electronics business. Since Taiwan is not recognized as an independent country by many governments worldwide, negotiating Free-Trade-Agreements is impossible. Also, Taiwan's influence on world politics is due to the size and the complicated China relations, meager. Nevertheless, with its proximity to China and a highly developed tech-sector, Taiwan has the chance to receive capital and knowledge from international enterprises. Positive development of this trade war for Taiwan is only possible with governmental intervention. The government should support businesses shifting production to Taiwan and provide sufficient funds for infrastructure measurement. Taiwan needs to be an attractive target for foreign companies to compensate for revenue streams from Chinese exports. Protectionism is here to stay, and there are no signs of an end of this trade dispute. Hence proper actions are necessary. When the right measures are taken, Taiwan has this unique opportunity of restructuring a former Chinese dominated supply chain with a higher Taiwanese influence, made in Taiwan could regain popularity.

Finally, Hong Kong's example has shown that China is very interested in tying its sovereign provinces more closely to itself or, at some point, taking them altogether. Therefore, a strong partner like the USA is indispensable if Taiwan wants to secure its independence in the future. Increased FDI flows from Taiwan's semiconductor companies in the US could help increase Washington's backing.

\section{References}

Asia Fund Managers. (2020). Taiwan Economy - GDP, Growth, Investments. Retrieved from https://www.asiafundmanagers.com/int/taiwan-economy/

Bergstein, C. F. (2010). Correcting the Chinese Exchange Rate: An Action Plan: Testimony before the Committee on Ways and Means, US House of Representatives. Peterson Institute for International Economics. Retrieved from https://www.piie.com/commentary/testimonies/correcting-chinese-exchange-rate-action-plan

Blakeley, G. (2019). The US-China trade war heats up: Why protectionism is here to stay. New Statesman, $148(5471), 17$.

Chen, Z., \& Haynes, K. E. (2016). A Short History of Technology Transfer and Capture: High-Speed Rail in China. SSRN Electronic Journal. https://doi.org/10.2139/ssrn.2872527

Ching, J. (2013). From Hardware to Tech Software: The Challenge Taiwan needs to overcome. Retrieved from https://vulcanpost.com/3447/from-hardware-to-tech-software-the-challenge-taiwan-needs-to-overcome-2/ 
The Economist. (2020). Burgernomics - The Big Mac index. The Economist. Retrieved from https://www.economist.com/news/2020/07/15/the-big-mac-index

Guo, M., Lu, L., Sheng, L., \& Yu, M. (2018). The Day After Tomorrow: Evaluating the Burden of Trump's Trade War. Asian Economic Papers, 17(1), 101-120. https://doi.org/10.1162/asep_a_00592

Hohensee, M., Menn, A., \& Petring, J. (2020). Der Stich ins Herz. Wirtschafts Woche, (041), 14-21.

Hsieh, W. (2020). Implications of the US-China Trade War for Taiwan. Asian Economic Papers, 19(1), 61-81. https://doi.org/10.1162/asep_a_00747

Johnson, M. (2017). US Country Commercial Guides: Taiwan. US Department of Commerce / International Trade Administration. Retrieved from https://www.export-u.com/CCGs/Taiwan\%20CCG\%202017.pdf

Kapustina, L., Lipková, L., Silin, Y., \& Drevalev, A. (2020). US-China Trade War: Causes and Outcomes. SHS Web of Conferences, 73(1). https://doi.org/10.1051/shsconf/20207301012

King, I., Martin, P., Wu, D., Gao, Y., \& Fabian, J. (2020, December 22). How Chinese Chip Giant SMIC Can Evade Trump's Newest Crackdown. Bloomberg. Retrieved from https://www.bloomberg.com/news/articles/2020-12-22/how-chinese-chip-giant-smic-can-evade-trump-s-ne west-crackdown

Moosa, N., Ramiah, V., Pham, H., \& Watson, A. (2020). The origin of the US-China trade war. Applied Economics, 52(35), 3842-3857. https://doi.org/10.1080/00036846.2020.1722797

Murthy, K. V. B., \& Kalsie, A. (2019). US-China currency and trade war: round one to China! Transnational Corporations Review, 11(4), 290-297. https://doi.org/10.1080/19186444.2019.1684134

National Bureau of Statistics of China. (2020a). Breakdown of Taiwan's gross domestic product (GDP) from 2015 to 2019, by economic sector. National Bureau of Statistics of China; Taiwan National Statistics. Retrieved from https://www.statista.com/statistics/321366/taiwan-gdp-breakdown-by-sector/

NDC. (2019). Taiwan Statistical Data Book. National Development Council ROC (Taiwan). Retrieved from https://www.ndc.gov.tw/en/News_Content.aspx?n=607ED34345641980\&sms=B8A915763E3684AC\&s=E DDF6690A4EE6CCB

OECD. (2019). OECD Trade Policy Papers (OECD Trade Policy Papers 1816-6873). Organization for Economic Co-Operation and Development (OECD). https://doi.org/10.1787/8fe4491d-en

Ramge, T. (2019). Chip, Chip, hurra! Brand Eins, (5), 18-23.

Taiwan Semiconductor Manufacturing Company. (2020). Company Info. TSMC. Retrieved from https://www.tsmc.com/english/aboutTSMC/company_profile

Wolverson, R. (2011). Confronting U.S.-China Economic Imbalances. Council on Foreign Relations (CFR). Retrieved from https://www.cfr.org/backgrounder/confronting-us-china-economic-imbalances

World Bank. (2019). Ease of Doing Business rankings. Retrieved from https://www.doingbusiness.org/en/rankings

Eletrochemical Society. (2016, January 29). Semiconductors Shaping Society. The Electrochemical Society. Retrieved from https://www.electrochem.org/semiconductors-shaping-society

Mozur, P. (2016, February 12). Obama Moves to Block Chinese Acquisition of a German Chip Maker. The New York Times. Retrieved from https://www.nytimes.com/2016/12/02/business/dealbook/china-aixtron-obama-cfius.html

Forsyth, R. W. (2016, June 4). Sorry, Trump, but Chinese Currency Is Actually Way Overvalued. Retrieved from https://www.barrons.com/articles/how-trinity-college-diversified-its-way-to-a-new-strength-51608226748

Loesche, D. (2018, April 4). Which Products Does America Export to China? Retrieved from https://www.statista.com/chart/13418/major-exports-from-the-us-to-china-by-goods-category/

Bennett, C., \& Bender, B. (2018, May 22). How China acquires 'the crown jewels' of US technology. Politico Investigation. POLITICO. Retrieved from https://www.politico.com/story/2018/05/22/china-us-tech-companies-cfius-572413

BBC (2019, January 2). Taiwan country profile. BBC News. Retrieved from https://www.bbc.com/news/world-asia-16164639

Ma, T. (2019, May 14). Impact of the escalating trade war on Taiwan. Singapore. DBS Bank. Retrieved from 
https://www.dbs.com/aics/templatedata/article/generic/data/en/GR/052019/190514_insights_impact_of_esc alating_trade_war_on_taiwan.xml\#

Taipei Times. (2019, August 30). TSMC report says its contribution to GDP was 4.46\%. 台北時報. Retrieved from https://www.taipeitimes.com/News/biz/archives/2019/08/31/2003721420

Bosch. (2019, October 4). Wussten Sie schon, dass... Fakten, Statistiken und Unglaubliches zu Halbleitern [Press release].

Retrieved from https://www.bosch-presse.de/pressportal/de/de/wussten-sie-schon-dass \%E2\%80\%A6-fakten-statistiken-und -unglaubliches-zu-halbleitern-200960.html

Semiconductor Industry Association. (2020, February 3). Worldwide Semiconductor Sales Decrease 12 Percent to \$412 Billion in 2019 [Press release]. Retrieved from https://www.semiconductors.org/worldwide-semiconductor-sales-decrease-12-percent-to-412-billion-in-201 9/

IMF. (April 2020). World Economic Outlook: The Great Lockdown. International Monetary Fund. Retrieved from https://www.imf.org/en/Publications/WEO/Issues/2020/04/14/weo-april-2020

Braw, E. (2020, April 15). China Wants to Buy Out US and EU Companies-and That is a National Security Threat. Foreign Policy. Retrieved from https://foreignpolicy.com/2020/04/15/china-is-bargain-hunting-and-western-security-is-at-risk/

Gladstone, R. (2020, July 22). How the Cold War Between China and the US. Is Intensifying: In defense, trade, technology, media, and diplomacy, among other areas, the rancor between the Trump administration and China's ruling Communist Party is worsening. The New York Times. Retrieved from https://www.nytimes.com/2020/07/22/world/asia/us-china-cold-war.html

Taiwan National Statistics. (August, 2020). Taiwan: GDP annual growth rate 2009-2021. Retrieved from https://www.statista.com/statistics/328535/gross-domestic-product-gdp-annual-growth-rate-in-taiwan/

Barrett, E. (2020, August 10). Semiconductors are a weapon in the U.S.-China trade war. Can this chipmaker serve both sides? Fortune. Retrieved from https://fortune.com/2020/08/10/us-china-trade-war-semiconductors-chips-tsmc-chipmakers/

Horton, C., \& Wu, R. (2020, September 13). Growing Distrust of China Brings \$38 Billion Taiwan Windfall. Retrieved from https://www.bloomberg.com/news/articles/2020-09-13/growing-distrust-of-china-brings-38-billion-windfall -for-taiwan

National Bureau of Statistics of China. (October 2020b). The unemployment rate in Taiwan from 2009 to 2019. Retrieved from https://www.statista.com/statistics/319838/taiwan-unemployment-rate/

Michaela, D. P., John, F. S. Jr., \& Karen, M. S. (2020, October 26). Semiconductors: US Industry, Global Competition, and Federal Policy. Congressional Research Service (CRS). Retrieved from https://fas.org/sgp/crs/misc/R46581.pdf

Miaojung, L., Horton, C., \& Wu, R. (2020, October 29). Taiwanese Growth Rebounds on Export Boom and Domestic Stimulus - Bloomberg. Bloomberg. Retrieved from https://www.bloomberg.com/news/articles/2020-10-29/taiwan-gdp-poised-for-rebound-buoyed-by-covid-res ponse-huawei

Wu, D., \& Ellis, S. (2020, November 27). Taiwan Raises GDP Forecast on Better-Than-Expected Exports. Bloomberg Quint. Retrieved from https://www.bloombergquint.com/china/taiwan-raises-2020-gdp-forecast-on-better-than-expected-exports

Chang, E. (2020, December 2). Intel considers tapping TSMC to produce its $7 \mathrm{~nm}$ chips. Taiwan News. Retrieved from https://www.taiwannews.com.tw/en/news/4067508

\section{Copyrights}

Copyright for this article is retained by the author(s), with first publication rights granted to the journal.

This is an open-access article distributed under the terms and conditions of the Creative Commons Attribution license (http://creativecommons.org/licenses/by/4.0/). 